\title{
Anti-proliferative role of recombinant lethal toxin of Bacillus anthracis on primary mammary ductal carcinoma cells revealing its therapeutic potential
}

\author{
Rekha Khandia ${ }^{1,6}$, Bramhadev Pattnaik ${ }^{2}$, Katherukamem Rajukumar ${ }^{1}$, Atul \\ Pateriya $^{1}$, Sandeep Bhatia ${ }^{1}$, Harshad Murugkar ${ }^{1}$, Anil Prakash ${ }^{3}$, Hare Krishna \\ Pradhan $^{4}$, Kuldeep Dhama ${ }^{5}$, Ashok Munjal ${ }^{6}$, Sunil K. Joshi ${ }^{7}$ \\ ${ }^{1}$ ICAR-National Institute of High Security Animal Diseases, Bhopal, Madhya Pradesh, India \\ ${ }^{2}$ Project Directorate on Foot and Mouth Disease, Mukteswar, Uttarakhand, India \\ ${ }^{3}$ Department of Microbiology, Barkatullah University, Bhopal, Madhya Pradesh, India \\ ${ }^{4}$ Ex-Avian Influenza National Consultant, Indian Office of WHO Consultant, Bhartiya Kala Kendra, New Delhi, India \\ ${ }^{5}$ Division of Pathology, ICAR-Indian Veterinary Research Institute, Izatnagar, Bareilly Uttar Pradesh, India \\ ${ }^{6}$ Department of Biochemistry and Genetics, Barkatullah University, Bhopal, Madhya Pradesh, India \\ ${ }^{7}$ Cellular Immunology Laboratory, Frank Reidy Research Center of Bioelectrics, College of Health Sciences, Old Dominion \\ University, Norfolk, VA USA
}

Correspondence to: Sunil K. Joshi, email: skjoshi@odu.edu Ashok Munjal, email: ashokmunjal70@yahoo.co.in

Keywords: anthrax toxin receptor, bacillus anthracis, c-Met receptor, lethal factor, protective antigen

Received: January 02, 2017 Accepted: March 07, 2017 Published: March 15, 2017

Copyright: Khandia et al. This is an open-access article distributed under the terms of the Creative Commons Attribution License (CC-BY), which permits unrestricted use, distribution, and reproduction in any medium, provided the original author and source are credited.

\section{ABSTRACT}

Bacillus anthracis secretes three secretary proteins; lethal factor (LF), protective antigen (PA) and edema factor (EF). The LF has ability to check proliferation of mammary tumors, chiefly depending on mitogen activated protein kinase (MAPK) signaling pathway. Evaluation of therapeutic potential of recombinant LF (rLF), recombinant PA (rPA) and lethal toxin (rLF + rPA = LeTx) on the primary mammary ductal carcinoma cells revealed significant $(p<0.01)$ reduction in proliferation of tumor cells with mean inhibition indices of $28.0 \pm 1.37 \%$ and $19.6 \pm 1.47 \%$ respectively. However, treatment with rPA alone had no significant anti-proliferative effect as evident by low mean inhibition index of $3.4 \pm 3.87 \%$. The higher inhibition index observed for rLF alone as compared to LeTX is contrary to the existing knowledge on LF, which explains the requirement of PA dependent endocytosis for its enzymatic activity. Therefore, the plausible existence of PA independent mode of action of LF including direct receptor mediated endocytosis or modulation of signal transduction cascade via unknown means is hypothesized. In silico protein docking analysis of other cellular receptors for any plausibility to play the role of receptor for $L F$ revealed C-Met receptor showing strongest affinity for $L F$ ( $H$ bond $=19$; Free energy $=-773.96$ ), followed by nerve growth factor receptor (NGFR) and human epidermal growth factor receptor (HER)-1. The study summarizes the use of rLF or LeTx as therapeutic molecule against primary mammary ductal carcinoma cells and also the c-Met as potential alternative receptor for LF to mediate and modulate PA independent signal transduction.

\section{INTRODUCTION}

Cancer remains a deadly malady despite several scientific advances and is one of the leading causes of deaths and high sufferings to the mankind. Though conventional therapies including of radiotherapy, chemotherapy and surgery are being followed widely; however due to their some limitations and side effects, 
researchers are continuously in the search of novel and alternative/complementary therapeutic options for countering various kinds of cancers and tumorous conditions. Some of such therapeutic regimens being explored include hormones inhibitors, immunotherapy (adjuvants, cytokines, TLR-agonists, immune-checkpoint inhibitors), apoptins (selective anti-cancer viral proteins), cryotherapy, molecular therapy (gene therapy, RNAi, CRISPR, Phages), homing peptides, herbs and plant metabolites, nanotechnology-based drug delivery as well as tumor vaccines, DNAzymes, HSP90 chaperone complex inhibitors, probiotic therapy, ribosome inactivating plant toxins, zootoxins derived from bees, snakes or scorpion, sponge toxins like agelasine B, or bacterial toxins and many others [1-10]. Several bacterial toxins are manipulated to specifically target tumor cells. These toxins include Clostridium difficile toxin [11, 12] Shiga-like toxin 1 [13, 14], Pseudomonas exotoxin A (PE) [15], Pertussis toxin [16] etc. Likewise, the same has been observed with lethal toxin of Bacillus anthracis [17]. In this direction, the present study reports the therapeutic role of recombinant lethal toxin of Bacillus anthracis, an etiological agent of anthrax, on primary mammary ductal carcinoma cells.

B. anthracis contains two toxin-encoding plasmids, namely, pXO1 and pXO2. The $181 \mathrm{~kb}$ pXO1 encodes for lethal factor (LF), protective antigen (PA) and edema factor (EF). The pXO2 encodes for the bacterial capsule, which prevents its phagocytosis by host immune cells [18]. Proteolysis of the mature PA, also known as PA83, by furin like proteases present in host cells, yields a $20 \mathrm{kDa}$ amino-terminal fragment, PA20 and a $63 \mathrm{kDa}$ carboxyl-terminal fragment, PA63 [19]. The biologically active PA63 forms a heptamer of PA63 which facilitates the binding and entry of LF and EF into the host cell cytoplasm through receptor mediated endocytosis [20]. The combination of LF and PA is called Lethal Toxin (LeTx). Lethal factor is a zinc dependent metalloprotease of $89 \mathrm{kDa}$ size and contains zinc-binding motif, HEXXH [21]. The substrates for LF are mitogenactivated protein kinase (MAPK) kinases (MEKs) [22]. It cleaves the N-termini of several intracellular MEK members viz. MEK1, MEK2, MEK3, MEK4, MEK6 and MEK7 [23, 24]. Cleavage of MEKs blocks several signal transduction pathways involved in the progression of cell cycle including the ERK (extracellular signalregulated kinase), p38 and JNK (c-Jun N-terminal kinase) pathways [23]. These pathways are involved in cell proliferation, differentiation and survival [25]. Unlimited cell growth is a typical feature of cancerous tissues and is characterized by elevated quantities of MAPK due to its role in cell cycle progression [26]. Lethal toxin treatment resulted in partial or complete remission in a sub-cutaneous xenograft melanoma model [27]. In vivo treatment of fibrosarcoma, the cell dependent on mitogen activated protein kinase kinases (MEKs) revealed reduced tumor growth with reduced vascularization upon treatment with lethal toxin (LeTx) [28]. The similar results have been demonstrated by Liu et al. [29], where reduced vascularization in the tumor was observed after engineered lethal toxin treatment. MAPKs activation is the result of a cascade, which starts with the binding of ligand with the c-Met tyrosine kinase receptor (product of c-Met proto-oncogene). Upon binding, the c-Met receptor dimerizes and both the units auto-phosphorylate at tyrosine residues, which in turn creates active binding sites for proteins mediating downstream signaling [30]. This downstream signaling leads to activation of the MAPK [31-34]. Elevated level of c-Met RNA, protein and a MET transcriptional profile is linked with the mammary tumor progression and c-Met mediated MAPK cascade activation (Figure 1) [35-38]. Since LF has the inherent property to cleave MEKs, its role in anti-proliferative effect on tumors can be hypothesized. Targeting of anthrax toxin receptors (ATR) provide a strategy to inhibit tumor growth by virtue of targeting tumor vascularization due to abundance of ATR on tumor vasculature [39].

The c-Met receptor is involved in the activation of MAPK downstream signaling, growth and differentiation and known to express on surface of tumor cells [34]. Apart c-Met receptors, several other receptors are also known to participate in tumor growth especially with regard to breast cancer. The examples are nerve growth factor receptor (NGFR) [40, 41], epidermal growth factor receptor (EGFR) [42, 43], fibroblast growth factor receptors (FGFR) [44, 45] and platelet-derived growth factor receptor (PDGFR) [46]. All these are the members of tyrosine kinase receptor family and many cancer therapies against these receptors are in clinical and preclinical status [47-49]. Therefore, the effect of recombinant rLF, rPA and LeTx proteins on cultured primary mammary ductal adenocarcinoma cells and the possible interactions (in silico) of c-Met, NGFR, EGFR, FGFR and PDGFR with LF protein were analyzed in the present study.

\section{RESULTS}

\section{In vitro study on primary mammary tumor cells}

Residual mammary tumor biopsy tissues of midaged women (more than 50 years old) were obtained from Ayushman Hospital, Bhopal, M.P., India. Histopathology reports (Data not shown) of these biopsy samples identified as mammary adenocarcinoma (ductal) grade III of T2N2 stage. Cytosmears revealed loose cohesive clusters of large pleomorphic cells with very few infiltrating lymphocytes ensuring proliferative/ antiproliferative effect of recombinant LF and PA proteins is restricted only to parenchymatous (neoplastic) cells. 


\section{Localization of proteins and yield}

Both the proteins were localized into inclusion body fraction and were found specific as indicated by western blot analysis (Figure 2). The yield of rLF and $\mathrm{rPA}$ is $1.5 \mathrm{mg} \mathrm{l}^{-1}$ and $8 \mathrm{mg} \mathrm{l}^{-1}$ of culture respectively (rLF-85kDa; rPA-63 kDa). Both the recombinant proteins (rLF and $\mathrm{rPA}$ ) were biologically active and possessing anti-angiogenic effect on CAM, evidenced by presence of mesodermal plexus, which failed to migrate to ectoderm. Additionally, rPA was found to cause hemorrhage in the treated CAM, indicative of its biological activity [50].

\section{Effect of recombinant proteins on proliferation of mammary tumor cells}

The results of the present study showed that both rLF and LeTx significantly $(p<0.01)$ reduced the proliferation of mammary tumor cells with mean inhibition indices of $28.0 \pm 1.37$ per cent and $19.6 \pm 1.47$ per cent respectively, however treatment with rPA alone had no statistically significant anti-proliferative effect as indicated by low mean inhibition index of $3.4 \pm 3.87$ percent (Figure 3). Since the LF is a metalloprotease and having capacity to cleave MAPK, it may be effective against several tumors, where cell cycle progression is largely dependent on MAPK signaling.

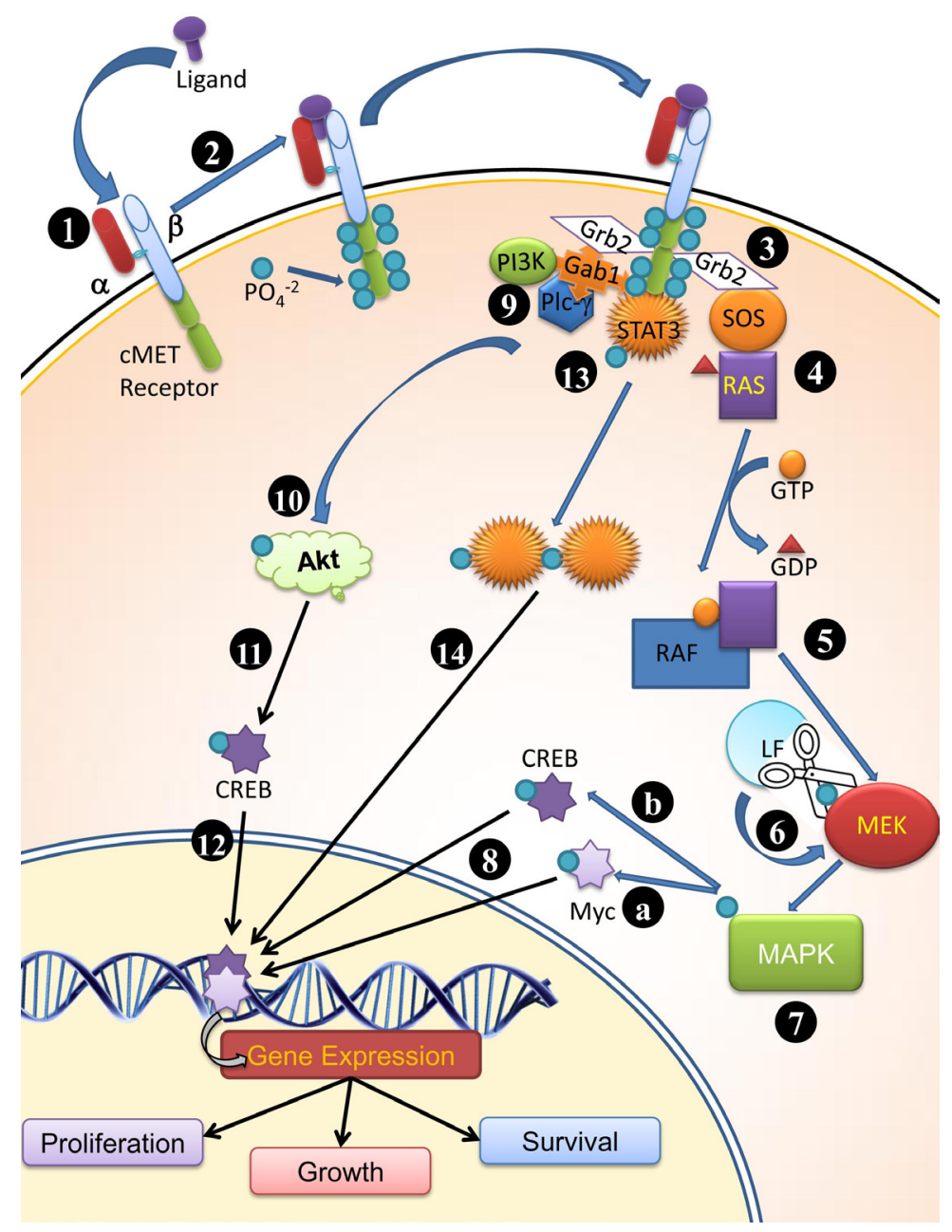

Figure 1: Plausible mode of functioning of cMET receptor (1) cMET is synthesized by hepatocytes. $\alpha$ subunit is extracellular; whereas the $\beta$ subunit is trans-membrane peptide possessing a kinase domain and docking site for molecule which participate in cell signaling and receptor bioactivity (2) upon ligand binding to the cMET receptor, the tyrosine kinase domain is highly phosphorylated at tyrosine residue (1234-1235, 1349, 1356 at $\mathrm{C}$ terminus of $\beta$ subunit ) (3) Grb2 effecter binds to phosphorylated tyrosine kinase and RAS guanine exchange factor SOS (Son of sevenless) (4) SOS promotes dissociation of GDP from Ras and attachment of GTP thereby activates Ras (5) Ras activates Raf and in turn (6) Phosphorylates MEK, followed by phosphorylation of MAPK; LF cleaves MEKs and prevent further downstream signaling required for cell proliferation, survival and growth. (7) MAPK activates Myc (7A) and CREB (7B) by phosphorylation and (8) These translocates into nucleus and bind to their respective response elements (9) Gab1 interacts with cMet receptor and provide binding site for SH2 domain containing proteins (Grb2, PI3K, PLC $\gamma$ ) (10) PI3K phosphorylates Akt, which in turn (11) phosphorylates CREB and (12) allow transcription of surviving genes (also 7B) (13) Post phosphorylation C terminus of $\beta$ subunit of the receptor acts as docking site for STAT3 and STAT3 is phosphorylated (14) Dimerized and translocated to nucleus for promoting different gene expressions. 


\section{Table 1: Results of in silico protein docking of receptors involved in cell proliferation and mammary tumor with LF using $H E X-8$ software}

\begin{tabular}{llll}
\hline S. No. & \multicolumn{1}{c}{$\begin{array}{c}\text { Name of receptor docked with LF protein (1JKY) } \\
\text { (B. anthracis) }\end{array}$} & $\begin{array}{c}\text { No. of hydrogen bonds } \\
\text { Fepatocyte growth factor receptor (c-Met receptor) (3DKC) }\end{array}$ & Free energy (e-total) \\
\hline 1 & Nerve growth factor receptor TrkA (1HE7) & 19 & -773.96 \\
2 & Human Epidermal Growth Factor HER1 (2ITX) & 13 & -561.83 \\
3 & Human Epidermal Growth Factor HER2 (3PP0) & 11 & -765.30 \\
4 & Human Epidermal Growth Factor HER3 (1M6B) & 20 & -388.29 \\
5 & Human Epidermal Growth Factor HER4 (3BCE) & 4 & -145.42 \\
6 & Human Platelet-Derived Growth Factor (1PDG) & 7 & -260.00 \\
7 & Fibroblast Growth Factor Receptor (1FGK) & 2 & -577.35 \\
8 & Protective antigen (B. anthracis) (4H2A) & 12 & -412.82 \\
9 & Protective antigen bound to Anthrax toxin receptor (1T6B) & 22 & -420.48 \\
10 & & & -402.6 \\
\hline
\end{tabular}

Here, it is noteworthy that rLF alone has caused more inhibition than LeTx, showing biological activity of the proteins produced as well as LF exhibited enzymatic function independent of PA, which have key role in trafficking of LF inside the cell. So presumably, apart from $\mathrm{PA}$, another receptor might exist for LF, which led to the further investigation through in silico analysis.

\section{In silico protein docking analysis reveals interaction between $\mathrm{LF}$ and c-Met receptors}

The results of in silico protein docking analysis of different receptors with LF have been given in Table 1. In the condition of anthrax toxin receptor (ATR) bound PA, the PA-LF interaction had $22 \mathrm{H}$ bonds and a free energy value of -402.6 , indicating higher number of $\mathrm{H}$ bonds but higher free energy. The software generated docking models for LF-PA, LF-PA-ATR and LF-c-Met interactions has been depicted in Figure 4A to 4C. Among the other receptors, NGFR and HER-1 showed good interactions with LF in terms of higher number of H-bonds and higher free energy values (Table 1). The present in silico analysis using HEX software, revealed a stronger interaction of c-Met and LF, suggesting c-Met as alternative receptor for LF traffic inside the cell or for modulating the signaling cascade upon binding.

The in silico protein docking analysis revealed the presence of a stronger interaction between LF and c-Met receptor $(\mathrm{H}$ bond $=19$; and Free energy $=-773.96)$ in comparison to that of between LF and PA $(\mathrm{H}$ bond $=$ 12 and Free energy $=-420.48)$. The data indicates that LF have stronger affiliation with c-Met in contrast to its

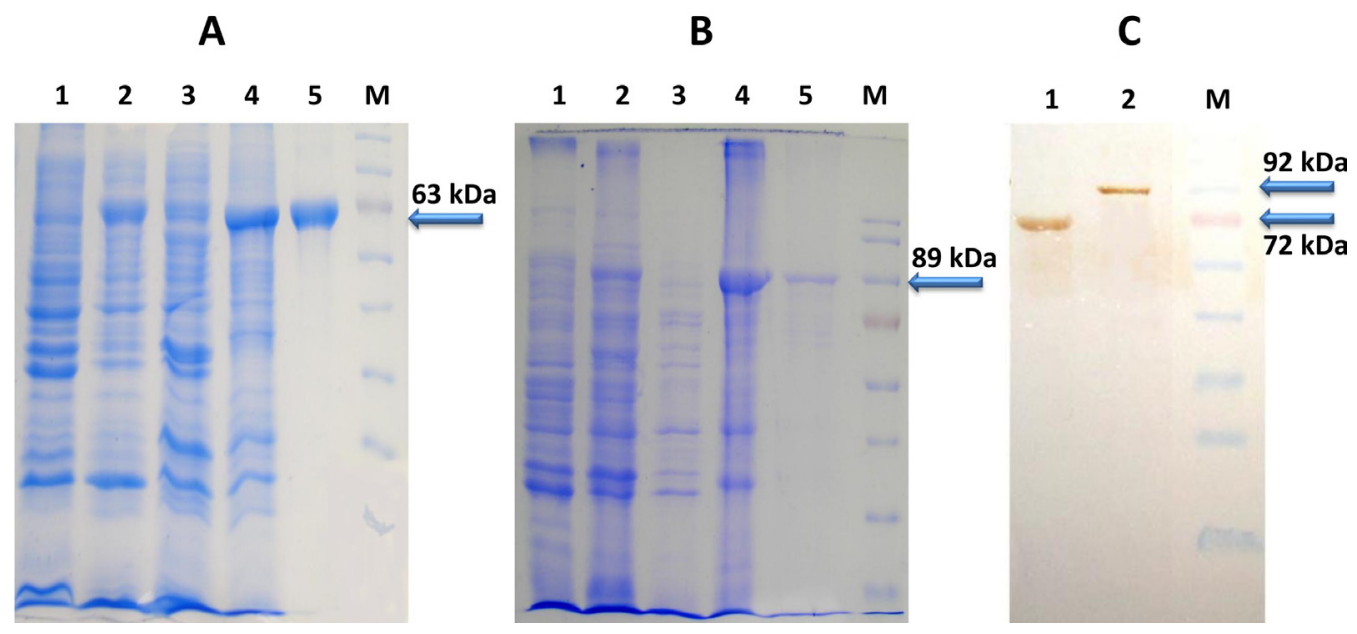

Figure 2: (A) SDS-PAGE analysis of E. coli expressed 6X His Tagged PA Protein (B) SDS-PAGE analysis of E. coli expressed 6X His Tagged LF Protein (Lane 1 corresponds to Rosettablue(DE3)pLysS E.coli cell lysate; lane 2- Total cell pellet of induced culture; Lane 3-Soluble fraction of cell lysate; Lane 4-Inclusion body fraction of cell lysate; Lane 5-Ni-NTA purified PA/ LF protein; Lane M- Molecular weight markers) (C) Western blot analysis of purified PA and LF proteins ( $\sim 63 \mathrm{kDa}$ PA protein and $\sim 85 \mathrm{kDa}$ LF protein) (Lane 1 corresponds to Purified PA63 protein; lane 2-Purified LF protein; Lane M- Molecular weight markers). 


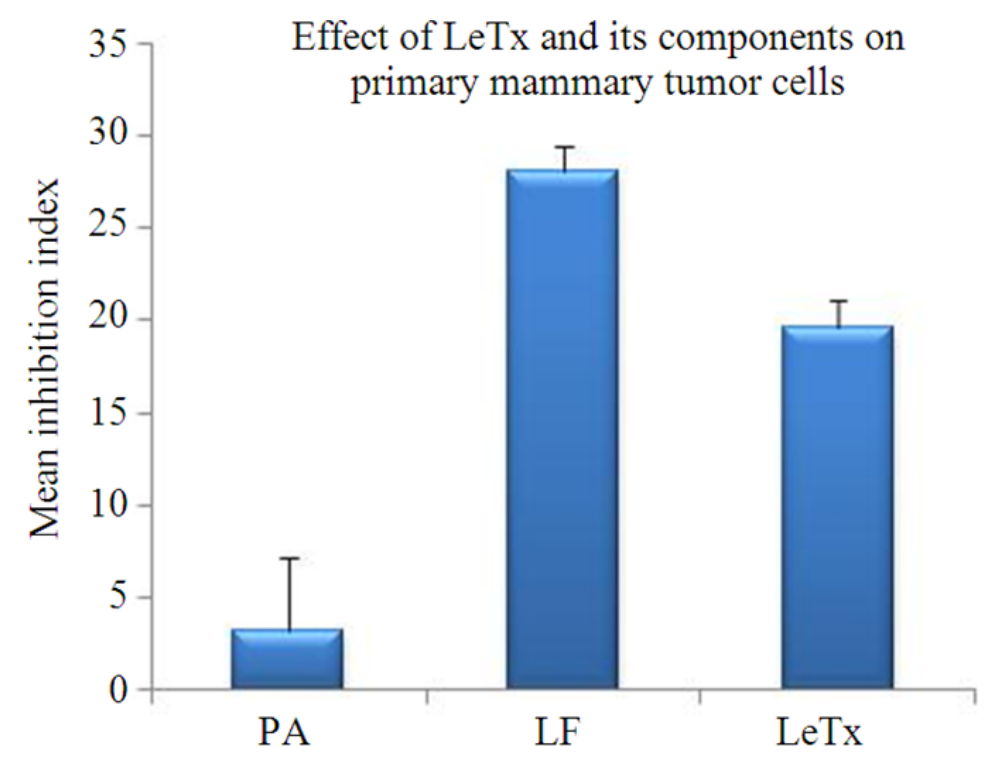

Figure 3: Decrease in proliferation caused by LeTx and its components was calculated as inhibition index and the values are shown as the mean $\pm \mathrm{SD}$ for a minimum of three independent replicates.

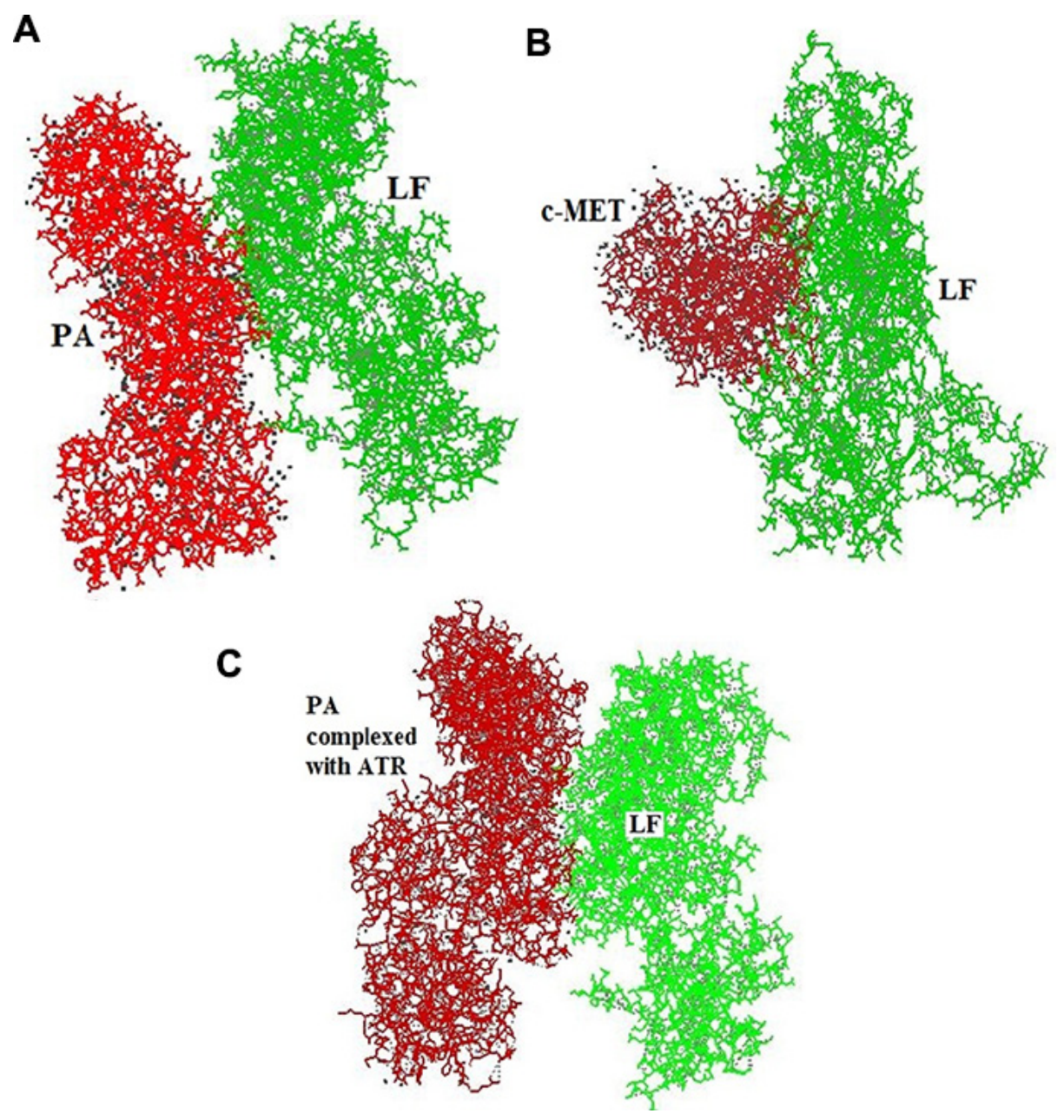

Figure 4: HEX-8 software generated docking model for (A) LF-PA interactions (B) LF-c-Met interactions (C) LF-PA interactions after complexing with ATR. 
Table 2: The suitable model for the site of interaction; between the amino-acid residues of c-Met receptor and $\mathrm{LF}$ using ClusPro

\begin{tabular}{cc}
\hline Residue no. of c-Met receptor & Residue no. of LF \\
\hline E1061 & K552 \\
E1064 & Q560 \\
Q1123 & R409 \\
D1133 & N626, R628 \\
K1193 & Q704, N703 \\
K1198 & E662, N626, G625 \\
K1199 & E662, H645 \\
D1231 & K410 \\
K1259 & E648, Y650 \\
T1262 & D647 \\
K1263 & P16 \\
S1331 & Q704 \\
S1335 & Q704 \\
\hline
\end{tabular}

natural counterpart PA. Since, the number of $\mathrm{H}$ bonds and minimum free energy are the indicator of stronger interaction and higher affinity. The portion of c-Met receptor between amino acid residues no. 1061 to 1335 interact with the amino acid residues no. 409 to 704 of LF (Table 2, Figure 5).

\section{DISCUSSION}

Mammary cancer is one of the most common cancers present among the females and accounts for approximately $25 \%$ deaths due to cancer. Several FDA approved drugs are being given as part of chemotherapy for treating breast cancer including Epirubicin, Doxorubicin, Daunorubicin and Cyclophosphamide, acting by damaging cancer cells and killing them; Everolimus, acting by inhibiting mTOR kinase; Pamidronate, acting by limiting the action of osteoclastic cells and thereby preventing metastasis in bone from mammary tissues, Anastrozole and Raloxifene by reducing the relapse of hormone-receptor-positive breast cancer; Bevacizumab, the only treatment act by targeting angiogenesis in breast cancer; Paraplatin, the only platinum base therapy, acting through damaging genetic material etc. However, these are all associated with some common problems including enhanced risk of stroke, headache, nausea, vomiting, abdominal pain, joint pain, muscle pain, diarrhea or constipation $[51,52]$. Trastuzumab, a humanized mAb targeting the HER2 receptor, displays a good overall survival of patient [53] however; pose threat of cardiac dysfunction [54]. Another approach to circumvent the mammary tumor cell growth is to target MAPK, a key enzyme in the RasRaf-MEK-Extracellular signal Regulated Kinase (ERK) kinase pathway, which is constitutively active in tumors including mammary tumor $[55,56]$. LeTx, a binary toxin produced by $B$. anthracis is catalytically a potent inhibitor of the MAPK pathway. It binds and internalizes within most of the tissues but is toxic only to cells dependent on MAPK signaling for survival. Considering the fact that mammary tumor cells over-express MAPK, which is an enzymatic substrate of lethal factor; hence, the inhibition in mammary tumor cells proliferation by LeTx can be hypothesized. Therefore, the effect of LeTx and its components (rLF, rPA) on proliferation of primary mammary tumor cells was evaluated in vitro.

Cell lines are widely accepted models for evaluation for antitumor therapeutic drugs, for retaining many genetic, epigenetic and gene expression features [57], but are more complex than tumor itself due to extensive chromosomal rearrangements, oncogene mutations, and multiple sites of allelic loss, gene amplification and probable change in some cellular pathways [58]. The difference in degree of aneuploidy and steroid receptor status between breast tumor and breast cancer cell lines [59-61] makes cell lines non-representative of the most common diverse type of tumors.

Different concentrations of PA and LF, ranging from $100 \mathrm{ng}$ to $1 \mu \mathrm{g}$ [62-66], have been used previously to see their cytotoxic effect on LeTx sensitive mouse macrophage like cell lines RAW264.7 and J774A and at this concentrations cytotoxicity was observed. Though cytotoxic dose of LeTx on mammary tumor cells is not known, a dose of $50 \mathrm{ng}$ of lethal factor, nontoxic even to LeTx sensitive cells, was used, to be assured that the effect of the recombinant protein on primary mammary cells is attributed to enzymatic or other cellular function 
and not due to cytotoxicity. The LF to PA ratio ranging from 1:3 to 1:5 has been demonstrated to have maximum anti-proliferative activity on melanoma tumor [67]. This information support the explanation of dosage of rLF to rPA in LeTx used in the present study (1:3 with 50 and $150 \mathrm{ng}$ of each antigen respectively).

Inhibition in proliferation of mammary tumor cells by LF and LeTx in this study (inhibition indices 28 and $19 \%$ ) demonstrates the potential use of LF and LeTx as therapeutic agent against tumors. Tumor endothelium marker-8 (TEM-8) and capillary morphogenesis protein-2 (CMG2) are the two types of ATR present on the surface of host cells. TEM8 is selectively upregulated in endothelial cells during blood vessel formation and in endothelial cells of neoplastic tissue; therefore toxicity of lethal toxin of $B$. anthracis may be targeted specifically to growing tumor vasculature [39]. This data further may be exploited in targeting solid tumors. Further studies are required to test their in vivo efficacy. Current literature on anthrax toxin activities states that $\mathrm{LF}$ and $\mathrm{EF}$ as individual proteins are inactive and they become functional only after binding to PA as binary toxin $(\mathrm{PA}+\mathrm{LF}=\mathrm{LeTx}$; $\mathrm{PA}+\mathrm{EF}=\mathrm{EdTx})[68,69]$. Protective antigen has been long considered as trafficking moiety facilitating entry of LF and EF into the cells through clathrin, actin and unconventional receptor mediated endocytosis $[39,70]$. In a previous study, intracellular expression of LF in human lung adenocarcinoma cell line was found to cause cytotoxic effect [71]. Contrary to the existing knowledge of PA dependent trafficking of LF, the higher inhibition index observed in the study for rLF alone as compared to that of LeTx is indicative of enzymatic activity of LF alone without the need of PA.

On the basis of above results, PA independent receptor mediated endocytosis or modulation of signal transduction cascade via binding to other unknown moieties can be hypothesized. To elucidate the possible interaction of LF with other cellular receptors i.e. c-Met, NGF, EGFR, FGF and PDGF, predominantly overexpressing on mammary tumor cells were checked in silico. NGF is reported to participate in neuronal cell survival and differentiation and there are growing evidences of role of NGF as major stimulator of breast cancer cell growth. The action of NGF is mediated by TrkA (tyrosine kinase receptor family) and p75NT (tumor necrosis factor receptor family) [40]. TrkA also known as high affinity nerve growth factor receptor and is major receptor [72]. Upon binding with ligand, it undergoes autophosphorylation and cascade of MAPK phosphorylation starts. p75NTR is a minor receptor which upon interacting with TrkA receptor, form high-affinity binding sites for NGF $[73,74]$. Being major receptor, TrkA receptor interaction was taken into account. It showed 15 hydrogen bonds and -561.83 of free energy. The second receptor, epidermal growth factor receptor (EGFR) is observed to be over expressed in all subtypes of breast cancer. The members of the epidermal growth factor receptor are EGFR (HER1), HER2 (also known as ErbB2), HER3 (also known as ErbB3), and HER4 (also known as ErbB4) [42]. Upon growth-factor binding,

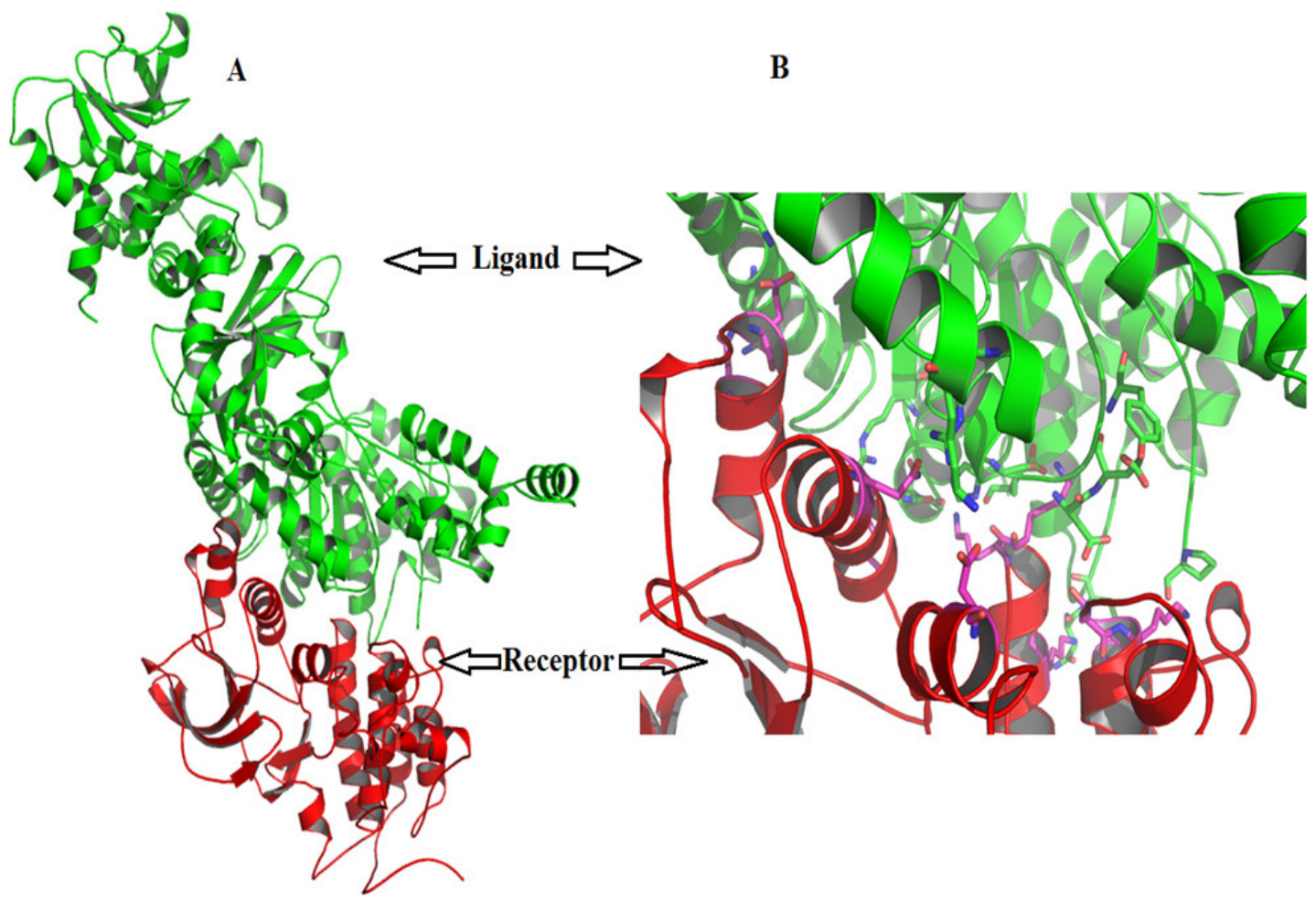

Figure 5: (A) The site of interactions of c-Met receptor with the LF using ClusPro (B) enlarged view of the same. 
EGFR family members homo- or hetero-dimerize and activate their cytoplasmic tyrosine kinase domains to initiate intracellular signaling $[75,76]$. Upon subjecting all EGFR interaction with LF, maximum interaction was shown by HER1 with 13 hydrogen bonds and -765.30 of free energy. Though HER3 exhibited more numbers of hydrogen bonds (20), but its free energy was more. HER2, which is over-expressed in $20 \%$ to $25 \%$ of breast cancers and is the well established therapeutic target in breast cancer [77] showed only 11 hydrogen bonds with -388.29 energy. HER4 receptor showed even less degree of interaction. The PDGF, are tyrosine kinase receptors, function in controlling development of mesenchymal cells, such as pericytes, fibroblasts and vascular smooth muscle cells [78]. In breast cancer, correlation of PDGF $\beta$-receptor expression is found [79]. The PDGF $\beta$-receptor also showed less degree of interaction ( $\mathrm{H}$ bond $=7$ with free energy $=-577.35$ ). FGFR family comprises four members, FGFR-1, $-2,-3$, and -4 [80]. The activation of signalling cascade involve binding of ligand to the extracellular domain of receptor and phosphorylation of the cytoplasmic tail of the receptor followed by activation of rat sarcoma mitogen-activated protein kinase (RAS-MAPK) pathway. The several studies have identified amplifications of FGFR1 in breast cancer [81, 82] and hence included in the study, but there are studies disapproving its role in cancer progression also [83]. In our study, poor interaction of FGFR with LF is observed in silico. The c-Met receptor, a product of proto-oncogene c-met [84], is a known tyrosine kinase receptor involved in many signaling pathways associated with growth, differentiation, motility, migration and invasion. Up regulation of c-Met receptor and MAPKs activation leading to cell proliferation has been reported in progressive mammary tumors [36]. Apart mammary cancer [85], cMET has been expressed in several cancers including advanced esophageal squamous cell carcinoma [86], lung cancer [87], Renal Cancer [88], Malignant skin cancer [89], pancreatic cancer [90] etc. Recently, inhibition of cMET has been demonstrated to display therapeutic effects in ovarian clear cell carcinoma (OCCC). Use of cMET inhibitors, like SU11274 or crizotinib, induce apoptosis and reduce proliferation of OCCC cells. Other inhibitors include other cMET targeting therapies for treating cancers including Monoclonal antibodies including Rilotumumab and Onartuzumab; Small molecule c-Met tyrosine kinase inhibitors (TKIs) including Tivantinib (ARQ197), AMG337 or Foretinib and c-Met targeting antibody ABT-700 [91, 92].

In silico docking analysis was performed to understand the possible interactions between LF and c-Met and compared to LF-PA as well as LF-PA-ATR interactions and it revealed a strong interaction between LF and c-Met receptor, as evident by presence of higher number of $\mathrm{H}$ bonds [19] and lower free energy $(-773.96)$ in comparison to its natural trafficking molecule PA. The higher number of $\mathrm{H}$ bonds [22] observed between LF and PA bound to ATR may be due to the conformational change in PA induced by PA-ATR interaction. Although the number of $\mathrm{H}$ bonds in the LF-c-Met interaction is less than that in the LF-PA-ATR interaction, the presence of lower free energy exhibited a thermodynamically more stable interaction due to the non-availability of energy to collide and react with other molecules. The results of this analysis suggests that out of 5 receptors envisaged in the study, LF binds with c-Met receptor strongly and possibly compete with other ligands which are involved in MAPK mediated cell proliferation pathways, leading to an inhibitory effect on tumor growth. Though, involvement of NGF and HER1 receptors can't be denied. Hence, we suggest c-Met receptor as one of the major possible molecule involved in the alternative strategy adapted by LF to perform its action in a PA independent manner either by modulating cellular signaling cascades or through LF internalization. Further studies are required in this direction.

\section{MATERIALS AND METHODS}

\section{Recombinant $B$. anthracis proteins}

The LF and PA genes were amplified using bacterial plasmid DNA as template. Primer FGCTAGCATTACTTTGAGTGGTCCCGTCTTT; Primer R-TCTAGAATGGCTGGTCCCGTTATT and Primer FAGTGCTCTCGAGACGGTTCCAGACCGTGAC Primer R-AAATCACGATCGATTACCTTACCTATCTC were used for amplification of LF and PA genes respectively. After a cloning step in pGEM-T easy vector (Promega, Madison, WI, USA) for sequencing, these genes were subcloned into pQE-31 (Qiagen, India) for LF gene and pET28(c) ${ }^{+}$for PA63 (Novagen, Billerica, MA, USA) respectively. The constructs were transformed into their respective expression host SG13009 and Rosetta blue (DE3) codon plus E. coli cells. Recombinant protein expression was induced by adding $1 \mathrm{mM}$ IPTG and the culture was induced for 4 hours. The cells were harvested by centrifugation and recombinant proteins were purified using Bug buster protein extraction reagent (Novagen). Soluble and inclusion body fraction was collected separately and run on $12.5 \%$ SDS polyacrylamide gel. The protein was characterized by western blot analysis using polyclonal serum raised in monkey against attenuated live anthrax spore vaccine. The recombinant proteins were purified using His Bind purification kit (Novagen) and subjected to refolding by protein refolding kit (Novagen) as per manufacturer protocol [93]. The protein was quantified using Qubit protein assay kit (Life Technologies, California, US). Biological activity of both the proteins was determined in chorioallantoic membrane (CAM) of embryonated chicken eggs for their effect on process of vascularization. 


\section{In vitro study on primary mammary tumor cells}

Residual mammary tumor biopsy tissues were provided by Dr. Sunita Yadav, MS, General and Cancer surgeon, Ayushman Hospital, Bhopal, M.P., India. The tissue were dissected and trypsinized (0.01\%) in RPMI medium. Cells were resuspended in RPMI medium supplemented with $10 \%$ FBS and seeded in a 96 well plate at a concentration of $5 \times 10^{3}$ cells per well in $100 \mu \mathrm{l}$ volume. Per microscopic field 3-4 infiltrating lymphocytes were present. Four test groups were prepared, each comprising triplicate wells. $100 \mu \mathrm{l}$ each of rPA (150 ng/well), in first set; rLF (50 ng/well) in second set; and LeTx [mixture of rPA (150 ng) + rLF (50 ng)] in third set of experiment were added in triplicate in 96 well plate (Nunc). For control group, $100 \mu \mathrm{l}$ RPMI media was added.

The plate was incubated at $37^{\circ} \mathrm{C}$ in $\mathrm{CO}_{2}(5 \%)$ incubator for $72 \mathrm{~h}$. Then $100 \mu \mathrm{l}$ of cell suspension was taken out and mixed with $50 \mu \mathrm{l}$ of MTT solution $\left(5 \mathrm{mg} \mathrm{ml}^{-1}\right)$. The plate was incubated at $37^{\circ} \mathrm{C}$ for additional $4 \mathrm{~h}$. Resulting formazon crystals were dissolved in $100 \mu \mathrm{l}$ of DMSO by vigorous pipetting and incubated at $37^{\circ} \mathrm{C}$ for $15 \mathrm{~min}$. Optical density (OD) was measured at $492 \mathrm{~nm}$ in a multi-well ELISA plate reader (Tecan, Japan). Inhibition index was calculated from the OD values using the following formula: Inhibition index $=\frac{\text { OD of control group }- \text { OD of treated group }}{\text { OD of control group }}$

The significance of difference between test groups was analyzed by student's $t$-test and $p$-value less than 0.01 was considered as significantly different.

\section{In silico docking analysis}

In order to compare and understand the interaction of LF (PDB: 1JKY) with PA (pH7.5; pdb-4H2A), PA bound to Anthrax Toxin Receptor (ATR) (PDB: 1T6B), c-Met (PDB: 3DKC) and other related group of receptors (NGFR, EGFR, FGFR and PDGFR); in silico analysis was carried out using $H E X-8$ protein docking software (http:// hex.loria.fr). Number of hydrogen bonds involved in the interactions between the docked proteins and the total free energy for each interaction were compared. Presence of higher number of $\mathrm{H}$ bonds and lower free energy indicated a stronger interaction between the proteins. The interaction between receptors and ligand was also confirmed using software ClusPro.

\section{CONCLUSIONS}

Results of the present study demonstrated the potential of rLF and LeTx for use as alternative therapeutics against mammary ductal carcinoma. Since mammary tumors are highly heterogeneous, the effect of LF and LeTx on other mammary tumor categories, need to be evaluated further. As indicated by the higher inhibition index observed for rLF alone as compared to that of LeTx, possible existence of PA independent modes of action of LF such as receptor mediated PA independent endocytosis or modulation of signal transduction cascade via other unknown interactions was hypothesized. In silico docking analysis also revealed the plausible existence of c-Met as an alternative receptor for LF to mediate and modulate PA independent signal transduction.

\section{ACKNOWLEDGMENTS AND FUNDING}

Rekha Khandia expresses her gratitude to DST, New Delhi for the financial assistance (WOS-A Project No. SR/WOS-A/LS-488/2013). All authors acknowledge and thank their respective Institutes and Universities.

\section{CONFLICTS OF INTEREST}

The researchers declare that they have no conflicts of interest.

\section{REFERENCES}

1. Pimentel AA, Felibertt P, Sojo F, Colman L, Mayora A, Silva ML, Rojas H, Dipolo R, Suarez AI, Compagnone RS, Arvelo F, Galindo-Castro I, De Sanctis JB, et al. The marine sponge toxin agelasine $\mathrm{B}$ increases the intracellular $\mathrm{Ca}^{2+}$ concentration and induces apoptosis in human breast cancer cells (MCF-7). Cancer Chemother Pharmacol. 2012; 69:71-83. doi: 10.1007/s00280-011-1677-x.

2. Dhama K, Chakraborty S, Wani MY, Verma AK, Deb R, Tiwari R, Kapoor S. Novel and emerging therapies safeguarding health of humans and their companion animals: a review. Pak J Biol Sci. 2013; 16:101-111.

3. Dhama K, Mani S, Chakraborty S, Tiwari, R, Kumar A, Selvaraj P, Rai RB. Herbal remedies to combat cancers in humans and animals-a review. Int J Curr Res. 2013; 5:1908-1919.

4. Khandia R, Sachan S, Munjal AK, Tiwari R, Dhama K. Tumor Homing Peptides: Promising Futuristic Hope for Cancer Therapy. Editors: Prof. Atta-ur-Rahman, FRS \& Dr. Khurshid Zaman- e-book. Volume 5 of Patent eBook series entitled "Topics in Anti-Cancer Research". Bentham Science Publishers. 2016; 43-86.

5. Dhama K, Latheef SK, Munjal AK, Khandia R, Abdul Samad H, Iqbal HM, Joshi SK. Probiotics in Curing Allergic and Inflammatory Conditions - Research Progress and Futuristic Vision. Recent Pat Inflamm Allergy Drug Discov. 2016. doi: 10.2174/1872213X106 66161226162229.

6. Khandia R, Munjal AK, Iqbal HMN, Dhama K. Heat Shock Proteins: Therapeutic Perspectives in Inflammatory Disorders. Recent Pat Inflamm Allergy Drug Discov. 2016, Bentham science publisher.

7. He ZM, Zhang PH, Li X, Zhang JR, Zhu JJ. A Targeted DNAzyme-Nanocomposite Probe Equipped with Built-in 
$\mathrm{Zn}^{2+}$ Arsenal for Combined Treatment of Gene Regulation and Drug Delivery. Sci Rep. 2016; 6:22737.

8. Shi M, Chen X, Ye K, Yao Y, Li Y. Application potential of toll-like receptors in cancer immunotherapy. Medicine (Baltimore). 2016; 95:e3951.

9. Polito L, Djemil A, Bortolotti M. Plant Toxin-Based Immunotoxins for Cancer Therapy: A Short Overview. Biomedicines. 2016; 4:12. doi: 10.3390/biomedicines4020012.

10. Mohanty I, Arunvikram K, Behera D, Milton AAP, Elaiyaraja G, Rajesh G, Dhama K. Immunomodulatory and Therapeutic Potential of Zootoxins (Venom and Toxins) on the Way Towards Designing and Developing Novel Drugs/Medicines: An Overview. Int J Pharmacol. 2016; 12:126-135.

11. Huang T, Li S, Li G, Tian Y, Wang H, Shi L, Perez-Cordon G, Mao L, Wang X, Wang J, Feng H. Utility of Clostridium difficile Toxin B for Inducing Anti-Tumor Immunity. PLoS One. 2014; 9:e110826. doi:10.1371/journal.pone.0110826.

12. Fogar P, Navaglia F, Basso D, Zambon CF, Moserle L, Indraccolo S, Stranges A, Greco E, Fadi E, Padoan A, Pantano G, Sanzari MC, Pedrazzoli S, et al. Heat-induced transcription of diphtheria toxin A or its variants, CRM176 and CRM197: implications for pancreatic cancer gene therapy. Canc Gene Ther. 2010; 17:58-68. doi: 10.1038/ cgt.2009.48.

13. Ryou JH, Sohn YK, Hwang DE, Kim HS. Shiga-like toxinbased high-efficiency and receptor-specific intracellular delivery system for a protein. Biochem Biophys Res Commun. 2015; 464:1282-9. doi: 10.1016/j.bbrc.2015.07.122.

14. Ibrahim OO. Expression of shiga-like toxin fused to vascular endothelial growth factor (VEGF/SLT) in E. coli for targeting angiogenesis. EC Pharmaceutical Sci. 2.3 2016; 338-355.

15. Michalska M, Wolf P. Pseudomonas Exotoxin A: optimized by evolution for effective killing. Front Microbiol. 2015; 6:963. doi: 10.3389/fmicb.2015.00963.

16. Orozco-Morales M, Sánchez-García FJ, Guevara-Salazar P, Arrieta O, Hernández-Pedro NY, Sánchez-García A, PerezMadrigal R, Rangel-López E, Pineda B, Sotelo J. Adjuvant immunotherapy of C6 glioma in rats with pertussis toxin. J Cancer Res Clin Oncol. 2012; 138:23-33. doi: 10.1007/ s00432-011-1069-y.

17. Bachran C, Leppla SH. Tumor Targeting and Drug Delivery by Anthrax Toxin. Toxins (Basel). 2016; 8. pii: E197. doi: 10.3390/toxins 8070197 .

18. Okinaka RT, Cloud K, Hampton O, Hoffmaster AR, Hill KK, Keim P, Koehler TM, Lamke G, Kumano S, Mahillon J, Manter D, Martinez Y, Ricke D, et al. Sequence and organization of $\mathrm{pXO1}$, the large Bacillus anthracis plasmid harboring the anthrax toxin genes. J Bacteriol. 1999; 181:6509-6515.

19. Singh Y, Klimpel KR, Goel S, Swain PK, Leppla SH. Oligomerization of anthrax toxin protective antigen and binding of lethal factor during endocytic uptake into mammalian cells. Infect Immun. 1999; 67:1853-1859.
20. Abrami L, Liu S, Cosson P, Leppla SH, Van Der Goot FG. Anthrax toxin triggers endocytosis of its receptor via a lipid raft-mediated clathrin-dependent process. J Cell Biol. 2003; 160:321-328. doi: 10.1083/jcb.200211018.

21. Jennifer BW, Lee CS, Duesbery N. Consequences and utility of the zinc-dependent metalloprotease activity of anthrax lethal toxin. Toxins. 2010; 2:1038-1053. doi: 10.3390/toxins 2051038 .

22. Duesbery NS, VandeWoude GF. Anthrax lethal factor causes proteolytic inactivation of mitogen-activated protein kinase kinase. J Applied Micro. 1999; 87:289-293. doi: 10.1046/j.1365-2672.1999.00892.x.

23. Vitale G, Pellizzari R, Recchi C, Napolitani G, Mock M, Montecucco C. Anthrax lethal factor cleaves the N-terminus of MAPKKS and induces tyrosine/threonine phosphorylation of MAPKS in cultured macrophages. J Applied Microbiol. 1999; 87:288-288. doi: 10.1046/j.13652672.1999.00893.x.

24. Devera TS, Prusator DK, Joshi SK, Ballard JD, Lang ML. Immunization of mice with anthrax Protective Antigen limits cardiotoxicity but not hepatotoxicity following Lethal Toxin challenge. Toxins 2015; 7: 2371-2384.

25. Wagner EF, Nebreda AR. Signal integration by JNK and p38 MAPK pathways in cancer development. Nat Rev Cancer. 2009; 9:537-49. doi: 10.1038/nrc2694.

26. Chopra AP, Boone SA, Liang X, Duesbery NS. Anthrax lethal factor proteolysis and inactivation of MAPK kinase. J Biol Chem. 2003; 278:9402-9406. doi: 10.1074/jbc. M211262200.

27. Abi-Habib RJ, Singh R, Leppla SH, Greene JJ, Ding $\mathrm{Y}$, Berghuis B. Systemic anthrax lethal toxin therapy produces regressions of subcutaneous human melanoma tumors in athymic nude mice. Clin Cancer Res. 2006; 12:7437-7443.

28. Ding Y, Boguslawski EA, Berghuis BD, Young JJ, Zhan Z, Hardy K, Furge K, Kort E, Frankel AE, Hay RV, Resau JH, Duesbery NS. Mitogen-activated protein kinase kinase signaling promotes growth and vascularization of fibrosarcoma. Mol Canc Ther. 2008; 7:648-658.

29. Liu S, Liu J, Ma Q, Cao L, Fattah RJ, Yu Z, Bugge TH, Finkel T, Leppla SH. Solid tumor therapy by selectively targeting stromal endothelial cells. Proc Natl Acad Sci USA. 2016; 113: E4079-87.

30. Ponzetto C, Bardelli A, Zhen Z, Maina F, Zonca P, Giordano S, Graziani A, Panayotou G, Comoglio PM. A multifunctional docking site mediates signaling and transformation by the hepatocyte growth factor/scatter factor receptor family. Cell. 1994; 77:261-271. doi: 10.1016/0092-867490318-2.

31. Peschard P, Park M. From tpr-met to met, tumorigenesis and tubes. Oncogene. 2007; 26:1276-1285. doi: 10.1038/ sj.onc. 1210201.

32. Seiden-Long I, Navab R, Shih W, Li M, Chow J, Zhu CQ, Radulovich N, Saucier C, Tsao MS. Gab1 but not Grb2 mediates tumor progression in Met overexpressing 
colorectal cancer cells. Carcinogenesis. 2008; 29:647-655. doi: $10.1177 / 1758834011422557$.

33. Trusolino L, Bertotti A, Comoglio PM. MET signalling: principles and functions in development, organ regeneration and cancer. Nat Rev Mol Cell Biol. 2010; 11:834-848. doi: 10.1038/nrm3012.

34. Organ SL, Tong J, Taylor P, St-Germain JR, Navab R, Moran MF, Tsao MS. Quantitative phospho-proteomic profiling of hepatocyte growth factor (HGF)-MET signaling in colorectal cancer. J Proteome Res. 2011; 10:3200-3211. doi: $10.1021 / \mathrm{pr} 200238 \mathrm{t}$.

35. Ho-Yen CM, Jones JL, Kermorgant S. The clinical and functional significance of c-Met in breast cancer: a review. Breast Cancer Research. 2014; 201517:52 doi: 10.1186/ s13058-015-0547-6.

36. Spina A, De Pasquale V, Cerulo G, Cocchiaro P, Morte RD, Avallone L, Pavone LM. HGF/c-MET Axis in Tumor Microenvironment and Metastasis Formation. Biomedicines. 2015; 3:71-88 doi:10.3390/biomedicines3010071.

37. Gao J, Inagaki Y, Song P, Qu X, Kokudo N, Tang W. Targeting c-Met as a promising strategy for the treatment of hepatocellular carcinoma. Pharmacol Res. 2012; $65: 23-30$.

38. Nakada M, Kita D, Watanabe T, Hayashi Y, Teng L, Pyko IV, Hamada J. Aberrant signaling pathways in glioma. Cancers (Basel). 2011; 3: 3242-3278.

39. Khandia R, Bhatia S, Chanu KV, Sood R, Dhama K. Anthrax Toxin Receptors, Functions and their Possible Use in Therapeutics: A Review. Asian J Anim Vet Adv. 2014; 9:599-609. doi: 10.3923/ajava.2014.599.609.

40. Molloy NH, Read DE, Gorman AM. Nerve Growth Factor in Cancer Cell Death and Survival. Cancers. 2011; 3:510-530. doi:10.3390/cancers301051.

41. Tsang JY, Wong KH, Lai MW, Lacambra MD, Ko CW, Chan SK, Lam CC, Yu AM, Tan PH, Tse GM. Nerve growth factor receptor (NGFR): a potential marker for specific molecular subtypes of breast cancer. J Clin Pathol. 2013; 66:291-6. doi: 10.1136/jclinpath-2012-201027.

42. Burness ML, Grushko TA, Olopade OI. Epidermal growth factor receptor in triplenegative and Basal-like breast cancer: promising clinical target or only a marker? Cancer J. 2010; 16:23-32. doi: 10.1097/PPO.0b013e3181d24fc1.

43. Masuda H, Zhang D, Bartholomeusz C, Doihara H, Hortobagyi GN, Ueno NT. Role of Epidermal Growth Factor Receptor in Breast Cancer. Breast Cancer Res Treat. 2013; 136.

44. Bello E, Colella G, Scarlato V, Oliva P, Berndt A, Valbusa G, Serra SC, D'Incalci M, Cavalletti E, Giavazzi R, Damia G, Camboni G. E-3810 is a potent dual inhibitor of VEGFR and FGFR that exerts antitumor activity in multiple preclinical models. Canc Res. 2011; 71:13961405. doi: 10.1158/0008-5472.CAN-10-2700.

45. Lamont FR, Tomlinson DC, Cooper PA, Shnyder SD, Chester JD, Knowles MA. Small molecule FGF receptor inhibitors block FGFR-dependent urothelial carcinoma growth in vitro and in vivo. Br J Canc. 2011; 4,104:75-82. doi: 10.1038/sj.bjc.6606016.

46. Weigel MT, Banerjee S, Arnedos M, Salter J, A'Hern R, Dowsett M, Martin LA. Enhanced expression of the PDGFR/Abl signaling pathway in aromatase inhibitorresistant breast cancer. Ann Oncol. 2013; 24:126-133.doi: 10.1093/annonc/mds240.

47. Bennasroune A, Gardin A, Aunis D, Crémel G, Hubert P. Tyrosine kinase receptors as attractive targets of cancer therapy. Crit Rev Oncol Hematol. 2004; 50:23-38.

48. Ségaliny AI, Tellez-Gabriel M, Heymann M, Heymann D. Receptor tyrosine kinases: Characterisation, mechanism of action and therapeutic interests for bone cancers. J Bone Oncol. 2015; 4:1-12.

49. Hojjat-Farsangi M. Small-Molecule Inhibitors of the Receptor Tyrosine Kinases: Promising Tools for Targeted Cancer Therapies. Int J Mol Sci. 2014; 15:13768-13801; doi:10.3390/ijms150813768.

50. Khandia R. Prokaryotic expression of PA63 and lethal factor of Bacillus anthracis and evaluation of antigenic and antiangiogenic activity. PhD Thesis, 2009. Barkatullah University, Bhopal, Madhya Pradesh, India.

51. Chatterjee K, Zhang J, Honbo N, Karliner JS. Doxorubicin Cardiomyopathy. Cardiology. 2010; 115:155-162. doi: $10.1159 / 000265166$.

52. Kenigsberg B, Campia U, Barac A. Cardiovascular side effects of cancer treatments. Clinical Pharmacist. 2016; 8:9. doi: 10.1211/CP.2016.20201651.

53. Slamon D, Eiermann W, Robert N, Pienkowski T, Martin M, Press M, Mackey J, Glaspy J, Chan A, Pawlicki M, Pinter T, Valero V, Liu MC, et al. Adjuvant trastuzumab in HER2positive breast cancer. N Engl J Med. 2011; 365:1273-1283. doi: 10.1056/NEJMoa0910383.

54. Giordano SH, Temin S, Kirshner JJ, Chandarlapaty S, Crews JR, Davidson NE, Esteva FJ, Gonzalez-Angulo AM, Krop I, Levinson J, Lin NU, Modi S, Patt DA, et al. Systemic therapy for patients with advanced human epidermal growth factor receptor 2-positive breast cancer: American Society of Clinical Oncology clinical practice guideline. J Clin Oncol. 2014; 32:2078-2099. doi: 10.1200/ JCO.2013.54.0948.

55. Hoshino R, Chatani Y, Yamori T, Tsuruo T, Oka H, Yoshida O, Shimada Y, Ari-i S, Wada H, Fujimoto J, Kohno M. Constitutive activation of the $41-/ 43-\mathrm{kDa}$ mitogenactivated protein kinase signaling pathway in human tumors. Oncogene. 1999; 8:813-22.

56. Low HB, Zhang Y. Regulatory Roles of MAPK Phosphatases in Cancer. Immune Netw. 2016; 16:85-98.

57. Van Staveren WC, Solis DY, Hebrant A, Detours V, Dumont JE, Maenhaut C. Human cancer cell lines: Experimental models for cancer cells in situ? For cancer stem cells? Biochim Biophys Acta. 2009; 1795:92-103.

58. Kao J, Salari K, Bocanegra M, Choi YL, Girard L, Gandhi J, Kwei KA, Hernandez Boussard T, Wang P, Gazdar AF, Minna JD, Pollack JR. Molecular profiling of 
breast cancer cell lines defines relevant tumor models and provides a resource for cancer gene discovery. PloS One. 2009; 4:6146.

59. Smith HS, Wolman SR, Hackett AJ. The biology of breast cancer at the cellular level. Biochim Biophys Acta. 1984; 738:103-123.

60. Wistuba II, Behrens C, Milchgrub S, Syed S, Ahmadian M, Virmani AK, Kurvari V, Cunningham TH, Ashfaq R, Minna JD, Gazdar AF. Comparison of features of human breast cancer cell lines and their corresponding tumors. Clin Canc Res.1998; 4:2931-8.

61. Levenson AS, Jordan CV. MCF-7: the first hormoneresponsivebreast cancer cell line. Canc Res. 1997; 57:3071-3078.

62. Hanna PC, Kochi S, Collier RJ. Biochemical and physiological changes induced by anthrax lethal toxin in $\mathrm{j} 774$ macrophage-like cells. Mol Biol Cell. 1992; 3:1269-1277.

63. Lin CG, Kao YT, Liu WT, Huang HH, Chen KC, Wang TM, Lin HC. Cytotoxic effects of anthrax lethal toxin on macrophage-like cell line J774A.1. Curr Microbiol. 1996; 33:224-227. doi: 10.1007/s002849900104.

64. Tang G, Leppla SH. Proteasome activity is required for anthrax lethal toxin to kill macrophages. Infect Immun. 1999; 67:3055-3060.

65. Gutting BW, Gaske KS, Schilling AS, Slaterbeck AF, Sobota L, Mackie RS, Buhr TL. Differential susceptibility of macrophage cell lines to Bacillus anthracis-vollum 1B. Toxicol in vitro. 2005; 19:221-229. doi: 10.1016/j. tiv.2004.08.007.

66. Joshi SK, Lang GA, Larabee JL, Devera TS, Aye LM, Shah HB, Ballard JD, Lang ML. Bacillus anthracis lethal toxin disrupts TCR signaling in CD1d-restricted NKT cells leading to functional anergy. PLoS Pathog. 2009; 5: e1000588.

67. Koo HM, VanBrocklin M, McWilliams MJ, Leppla SH, Duesbery NS, VandeWoude GF. Apoptosis and melanogenesis in human melanoma cells induced by anthrax lethal factor inactivation of mitogen-activated protein kinase kinase. Proc Nat Acad Sci. 2002; 99:30523057. doi: 10.1073/pnas.052707699.

68. Fish DC, Mahlandt BG, Dobbs JP, Lincoln RE. Purification and properties of In vitro-produced anthrax toxin components. J Bactitiol. 1968; 95:907-918.

69. Lacy DB, Collier RJ. Structure and function of anthrax toxin. Curr Top Microbiol Immunol. 2002; 271:61-85.

70. Abrami L, Bischofberger M, Kunz B, Groux R, Van der Goot FG. Endocytosis of the anthrax toxin is mediated by clathrin, actin and unconventional adaptors. PloS Pathog. 2010; 5:e1000792-e1000792. doi: 10.1371/journal. ppat. 1000792

71. Zhuo W, Guangli T, Zhang L, Chen Z. Vector-mediated selective expression of lethal factor, a toxic element of Bacillus anthracis, damages A549 cells via inhibition of MAPK and AKT pathways. Int J Med Sci. 2013; 10:292-298. doi: 10.7150/ijms.5570.
72. Lagadec C, Meignan S, Adriaenssens E, Foveau B, Vanhecke E, Romon R, Toillon RA, Oxombre B, Hondermarck H, Bourhis XL. TrkA overexpression enhances growth and metastasis of breast cancer cells. Oncogene. 2009; 28:1960-70. doi: 10.1038/onc.2009.61.

73. Reichardt LF. Neurotrophin-regulated signalling pathways. Philos Trans R Soc Lond B Biol Sci. 2006; 29,361:1545-1564. doi: 10.1098/rstb.2006.1894.

74. Skeldal S, Matusica D, Nykjaer A, Coulson EJ. Proteolytic processing of the 75 neurotrophin receptor. A prerequisite for signalling? Neuronal life, growth and death signalling are crucially regulated by intra-membrane proteolysis and trafficking of p75(NTR). BioEssays. 2011; 33:614-625.

75. Yarden, Y, Sliwkowski MX. Untangling the ErbBsignalling network. Nat Rev Mol Cell Biol. 2001; 2:127-37.

76. Schlessinger J. Ligand-induced, receptor-mediated dimerization and activation of EGF receptor. Cell. 2002; 110:669-672.

77. Prosnitz LR, Iglehart JD, Winer EP. Chapter 17: Breast cancer. In Clinical Oncology: A Multi-disciplinary Approach for Physicians and Students, 8th edn, 2001; 267-273. Eds P Rubin \& JP Williams. Waltham, MA, USA: Elsevier health sciences.

78. Betsholtz C. Insight into the physiological functions of PDGF through genetic studies in mice. Cytok Growth Fact Rev. 2004; 15:215-28.

79. Paulsson J, Sjöblom T, Micke P, Pontén F, Landberg G, Heldin CH, Bergh J, Brennan DJ, Jirström K, Ostman A. Prognostic Significance of Stromal Platelet-Derived Growth Factor $\beta$-Receptor Expression in Human Breast Cancer. Am J Pathol. 2009; 175: 334-341. doi: 10.2353/ ajpath.2009.081030.

80. Turner N, Grose R. Fibroblast growth factor signalling: from development to cancer. Nat Rev Canc. 2010; 10:11629. doi: $10.1038 / \mathrm{nrc} 2780$.

81. Moelans CB, de Weger RA, Monsuur HN, Vijzelaar R, Diest PJ. Molecular profiling of invasive breast cancer by multiplex ligation-dependent probe amplificationbased copy number analysis of tumor suppressor and oncogenes. Mod Pathol. 2010; 23:1029-1039. doi:10.1038/ modpathol.2010.84.

82. Tomiguchi M, Yamamoto Y, Yamamoto-Ibusuki M, GotoYamaguchi L, Fujiki Y, Fujiwara S, Sueta A, Hayashi M, Takeshita T, Inao T, Iwase H. Fibroblast growth factor receptor-1 protein expression is associated with prognosis in estrogen receptor-positive/human epidermal growth factor receptor-2-negative primary breast cancer. Canc Sci. 2016; 107:491-8. doi: 10.1111/cas.12897.

83. Kadota M, Sato M, Duncan B, Ooshima A, Yang HH, Diaz-Meyer N, Gere S, Kageyama S, Fukuoka J, Nagata T, Tsukada K, Dunn BK, Wakefield LM, Lee MP. Identification of novel gene amplifications in breast cancer and coexistence of gene amplification with an activating mutation of PIK3CA. Canc Res. 2009; 69:7357-7365. doi:10.1158/0008-5472.CAN-09-0064. 
84. Cooper CS, Park M, Blair DG, Tainsky MA, Huebner K. Molecular cloning of a new transforming gene from a chemically transformed human cell line. Nature. 1984; 311:29-33.

85. Ho-Yen CM, Jones JL, Kermorgant S. The clinical and functional significance of c-Met in breast cancer: a review. Breast Canc Res. 2015; 17:52.

86. Xu Y, Peng Z, Li Z, Lu M, Gao J, Li Y, Li Y, Shen L. Expression and clinical significance of c-Met in advanced esophageal squamous cell carcinoma. BMC Canc. 2015; 15:6.

87. Lv H, Shan B, Tian Z, Li Y, Zhang Y, Wen S. Soluble c-Met is a reliable and sensitive marker to detect c-Met expression level in lung cancer. Biomed Res Int. 2015;2015:626578. doi:10.1155/2015/626578.

88. Balan M, Mier y Teran E, Waaga-Gasser AM, Gasser M, Choueiri TK, Freeman G, Pal S. Novel roles of c-Met in the survival of renal cancer cells through the regulation of HO-1 and PD-L1 expression. J Biol Chem. 2015; 290:8110-20. doi: 10.1074/jbc.M114.612689.
89. Lee YJ, Kim DH, Lee SH, Kim DW, Nam HS, Cho MK. Expression of the c-Met Proteins in Malignant Skin Cancers. Ann Dermatol. 2011; 23:33-38.

90. Herreros-Villanueva M, Zubia-Olascoaga A, Bujanda L. c-Met in pancreatic cancer stem cells: Therapeutic implications. World J Gastroenterol. 2012; 18:5321-5323.

91. Kim HJ, Yoon A, Ryu JY, Cho YJ, Choi JJ, Song SY, Bang H, Lee JS, Cho WC, Choi CH, Lee JW, Kim BG, Bae DS. c-MET as a potential therapeutic target in ovarian clear cell carcinoma. Sci Rep. 2016; 6:38502. doi: 10.1038/ srep38502.

92. Marano L, Chiari R, Fabozzi A, De Vita F, Boccardi V, Roviello G, Petrioli R, Marrelli D, Roviello F, Patriti A. c-Met targeting in advanced gastric cancer: An open challenge. Canc Lett. 2015; 365:30-36.

93. Hochuli E, Bannwarth W, Dobeli H, Gentz R, Stüber D. Genetic approach to facilitate purification of recombinant proteins with a novel metal chelate adsorbent. Nat Biotechnol. 1988; 6:1321-1325. 